\title{
PARTICULATE MATTER SOURCE APPORTIONMENT IN COMPLEX URBAN AND INDUSTRIAL CITIES: THE CASE OF TARRAGONA, SPAIN
}

\author{
EDSON PLASENCIA SÁNCHEZ ${ }^{1}$, MANEL SÁNCHEZ-GUIJARRO ${ }^{1}$, \\ FRANCISCO SÁNCHEZ-SOBERÓN ${ }^{2}$, JOAQUIM ROVIRA² ${ }^{2}$ JORDI SIERRA $^{2}$, \\ MARTA SCHUHMACHER ${ }^{2}$, MÒNICA ROSELL ${ }^{1}$ \& ALBERT SOLER ${ }^{1}$ \\ ${ }^{1}$ Grup MAiMA, Mineralogia Aplicada, Geoquímica i Geomicrobiologia, Departament de Mineralogia, \\ Petrologia i Geologia Aplicada, Facultat de Ciències de la Terra, Universitat de Barcelona (UB), Spain \\ ${ }^{2}$ Universitat Rovira i Virgili (URV), Environmental Analysis and Management Group, \\ Departament d'Enginyeria Química, Spain
}

\begin{abstract}
In the framework of UltraPAR project (Assessing the Exposure and the Health Effects of Ambient Fine and Ultrafine Particles in areas of intensive industrial activity) the outdoor air quality of 12 schools in Tarragona (Catalonia, Spain) was monitored in winter 2016-2017. High volume air samplers equipped with quartz filters were used for sampling airborne particulate matter equal or smaller than 10,2.5, and $1 \mu \mathrm{m}$ (known as $\mathrm{PM}_{10}, \mathrm{PM}_{2.5}$, and $\mathrm{PM}_{1}$ respectively). These ambient samples together with some sources samples (harbour, industrial complexes, incinerator and road traffic) were chemically, mineralogically, and isotopically characterized and it is expected to help assessing the contribution of different emission sources. Preliminary results show that the maximum PM concentrations reached 37 $\mu \mathrm{g} / \mathrm{m}^{3}$ for $\mathrm{PM}_{1}, 30 \mu \mathrm{g} / \mathrm{m}^{3}$ for $\mathrm{PM}_{2.5}$ and $54 \mu \mathrm{g} / \mathrm{m}^{3}$ for $\mathrm{PM}_{10}$ while the lead content varies in the range of 10 to $13 \mathrm{ng} / \mathrm{m}^{3}$. Through XRD and SEM the marine aerosol influence is confirmed in this coastal city. The carbon isotopic signatures of the different PM sizes could be a potential tracer of its origin (mineral vs combustion sources). These findings were also compared with recent and older environmental data from other studies in similar cities or specifically in this zone to explore its consistency and possible temporal variations.
\end{abstract}

Keywords: PM10, PM 2.5, Carbon Isotopes, Tarragona.

\section{INTRODUCTION}

The metal profile and the isotopic composition of particulate matter (PM) have been used for identifying their emission sources, i.e. industrial or exhaust emissions, road dust, cement, biomass burning and others [1]-[3].

Several authors pointed out that industrial and coastal cities are principally affected by the industrial emission, marine aerosol, crustal and the traffic [4]-[7].

In Tarragona some studies have been performed in order to characterize the air quality and the potential health risk for exposed population, in most of them the principal component analysis (PCA) applied to a dataset of element abundance was the method used to estimate the source apportionment of pollutants [8]-[10].

\section{METHODOLOGY}

\subsection{Site description and sampling campaign}

Tarragona is located in northeast Spain on the shore of Mediterranean Sea at 90km southwest of Barcelona. Since 1960s it has experienced an extensive development in the chemical and petrochemical industries along with port activities and urban growing. 
In the framework of UltraPAR project, 12 schools were chosen in such a way that they were distributed around the petrochemical complex, the harbour and the industrial complex as show in Fig. 1.

The outdoor air quality was monitored in winter 2016-2017 using high volume air samplers equipped with quartz filters for $\mathrm{PM}_{10}, \mathrm{PM}_{2.5}$ and $\mathrm{PM}_{1}$ particles.

At each school, after 24 hours of sampling, the 3 filters were wrapped separately with aluminium foil and stored along with field blanks in a refrigerator at $-60^{\circ} \mathrm{C}$ until analysis. Besides, 8 samples from potential sources (i.e. gasoline and diesel cars, industrial harbour, municipal solid waste incineration plant, domestic fireplace, and 3 blind industrial samples provided by l'Associació Empresarial Química de Tarragona (AEQT) were analysed. Out of these 8 sources, 5 were collected as powder and 3 onto quartz fibre filter.

\subsection{Laboratory analysis and quality controls}

At URV the PM content was determined by gravimetric difference. Major and trace elements were determined by ICP-OES (Perkin Elmer Optima 8300) and ICP-MS (Perkin Elmer Elan 6000), soluble anions and cations by Ion Chromatography (Dionex DX-300), and content of total and elemental carbon was obtained by means of pyrolysis coupled to gas chromatography (Thermo EA 1108 CHNS-O Carlo Erba Instruments).

At the Centres Científics i Tecnològics de la Universitat de Barcelona (CCiT-UB) all the atmospheric filters and source samples were analyzed by X-Ray diffraction, XRD (PANalytical X'Pert PRO MPD Alphal powder diffractometer) and by scanning electron microscopy with energy-dispersive X-ray spectroscopy (SEM-EDS, Quanta 200 FEI XTE 325/D8395-Genesi, EDAX) and also, the carbon isotopic composition was obtained using an Elemental Analyser, EA (Carlo Erba Flash 1112) coupled to an Isotope Ratio Mass Spectrometer, IRMS (Delta C Thermo Fisher Scientific) through an interface Conflo III (MAT Thermo Finnigan). Field blanks were also analysed.

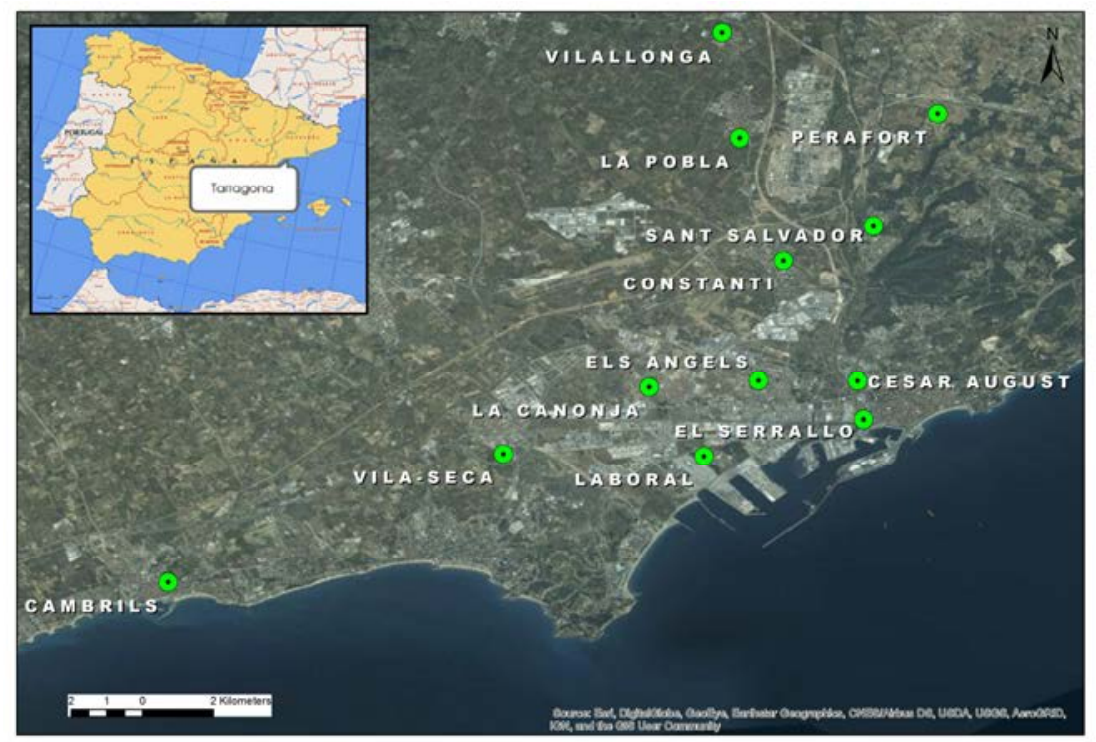

Figure 1: Location of the 12 sampled schools at Tarragona (Spain), showing the dominant winds. 


\subsection{Data analysis}

The total major element content in PM (Major-PM) was calculated as the sum of $\mathrm{Al}, \mathrm{Ca}, \mathrm{Fe}$, $\mathrm{K}, \mathrm{Mg}$ and Na content. The total trace element content in PM (Trace-PM) result of subtracting Major-PM from the sum of the 52 elements analysed (Al, As, Ba, Be, Bi, Ca, Cd, Ce, Co, Cr, $\mathrm{Cs}, \mathrm{Cu}$, Dy, Er, Eu, Fe, Ga, Gd, Ge, Hf, Hg, Ho, K, La, Li, Mg, Mn, Mo, Na, Nb, Nd, Ni, Pb, $\mathrm{Pr}, \mathrm{Rb}, \mathrm{Sb}, \mathrm{Sc}, \mathrm{Sm}, \mathrm{Sn}, \mathrm{Sr}, \mathrm{Ta}, \mathrm{Tb}, \mathrm{Th}, \mathrm{Ti}, \mathrm{Tl}, \mathrm{U}, \mathrm{V}, \mathrm{W}, \mathrm{Y}, \mathrm{Yb}, \mathrm{Zn}, \mathrm{Zr}$ ) in each filter.

The total nitrogen content in PM (N) was calculated as the sum of the nitrogen content in $\mathrm{NO}_{2}{ }^{-}, \mathrm{NO}_{3}{ }^{-}$and $\mathrm{NH}_{4}{ }^{+}$ions. The total major non-metal element content in PM (MajorNonMPM) was calculated as the sum of $\mathrm{N}, \mathrm{C}, \mathrm{S}, \mathrm{Cl}, \mathrm{P}$ and Se.

When the value of an element was lower of its limit of quantification (LOQ) a half of the LOQ was assigned to perform numerical operations over the whole data.

Maps were generated in ArcGIS 10.2 and statistical analysis was performed in Statgraphics XVII.

\section{RESULTS AND DISCUSSION}

\subsection{PM pollution levels}

In general, the concentrations of PM were moderate and near to the European air quality standard (EU Directive 2008/50/EC; $50 \mu \mathrm{g} / \mathrm{m}^{3}$ for $\mathrm{PM}_{10}$ and $25 \mu \mathrm{g} / \mathrm{m}^{3}$ for $\mathrm{PM}_{2.5}$ ) in the outdoor air of the 12 sampled schools in Tarragona. However, samples from Vilallonga not only were exceeding these AQS for $\mathrm{PM}_{10}$ and $\mathrm{PM}_{2.5}$, but also were above the percentile 95 th of the whole dataset (Fig. 2).

Perafort have a PM profile lower than Cambrils which is considered as an urban background area, probably, because is located inland and Cambrils is near to the coast.

Similar to at Els Angels, La Pobla and Vilallonga the $\mathrm{PM}_{1}$ fraction must be representing most of the $\mathrm{PM}_{2.5}$ content due to their close values.

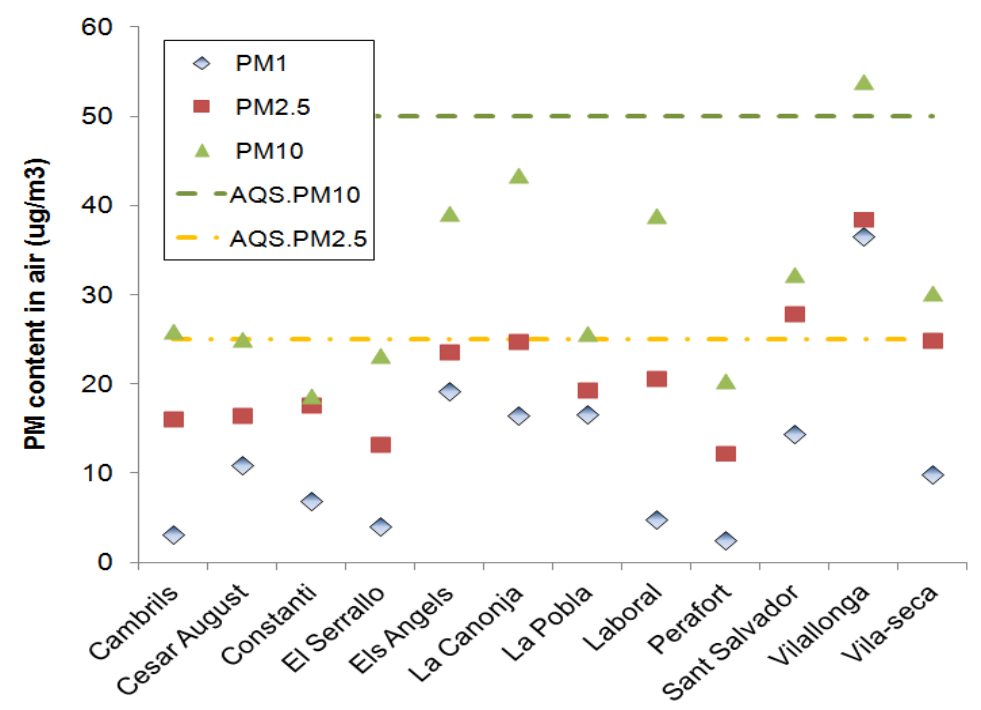

Figure 2: $\quad$ PM concentrations in the outdoor air of 12 schools in Tarragona respect air quality standards (AQS). 
The metal content (Major-PM + Trace-PM) was quite similar for $\mathrm{PM}_{10}$ and $\mathrm{PM}_{2.5}$ samples around $30 \%$ while for $\mathrm{PM}_{1}$ is around $10 \%$. There is not a clear relationship between the levels of metal content and PM, but, in general, as long as PM concentration increases the metal content decreases down to $20 \%$ in both $\mathrm{PM}_{10}$ and $\mathrm{PM}_{2.5}$ particles and down to less than $1 \%$ in $\mathrm{PM}_{1}$. In other words, the source of non-metal content for PM is larger than the source of metal content (i.e. sea aerosol o organic emissions vs particulate emission from engine wear) in such a way that metal content reach a maximum before than the non-mental content in PM.

The metal content suggests 3 areas of influence: near industrial source or roads (higher $\mathrm{PM}_{1}$ content), urban or surrounding industrial complexes (similar $\mathrm{PM}_{10}$ and $\mathrm{PM}_{2.5}$ content) and influenced by marine, dust or a secondary emission source (increasing the amount of PM but not the metal content).

Attending to its extreme low metal content, the road traffic apportionment at Cambrils, El Serrallo, Laboral and Perafort (all they near to the coast) can be considered negligible beside to other pollution sources, at least in a preliminary sense.

It has to be taken into consideration that a high variability of PM levels at Tarragona has been reported previously and it was explained by the influence of external air masses from Sahara, Barcelona and inner Europe [11], [12].

\subsection{Elemental composition}

The most abundant element (as weight percent) in $\mathrm{PM}_{10}$ and $\mathrm{PM}_{2.5}$ samples was $\mathrm{Na}$, indeed, $\mathrm{Na}, \mathrm{Al}, \mathrm{Ca}$ represent around $80 \%$ of the total metal content in all these samples. All samples had similar composition both in Major-PM and Trace-PM, except Cambrils where $\mathrm{Na}$ represent more than $60 \%$ in $\mathrm{PM}_{2.5}$ and Ca represent more than $80 \%$ in $\mathrm{PM}_{1}$.

In Fig. 3 is shown the metal composition of $\mathrm{PM}_{1}$ samples after $\mathrm{Na}, \mathrm{Al}, \mathrm{Ca}$ and $\mathrm{K}$ were removed. The contents of $\mathrm{Mg}, \mathrm{Cu}, \mathrm{Fe}, \mathrm{Sc}, \mathrm{Sn}$ and $\mathrm{Zn}$ were significant although different between samples. Vilaseca, Vilallonga and Sant Salvador got the most similar element composition (as weight percent), while Cesar August had the highest content of Fe, El Serrallo of $\mathrm{Cu}$, Perafort of $\mathrm{Mg}$ and La Pobla of $\mathrm{Sb}$ and $\mathrm{Sn}$.

From the major nonmetal elements, carbon was the most prevalent in all samples, except for Cambrils $\left(\mathrm{PM}_{10}, \mathrm{PM}_{2.5}\right.$ and $\left.\mathrm{PM}_{1}\right)$, Laboral $\left(\mathrm{PM}_{10}\right)$, Sant Salvador $\left(\mathrm{PM}_{2.5}\right)$ and El Serrallo

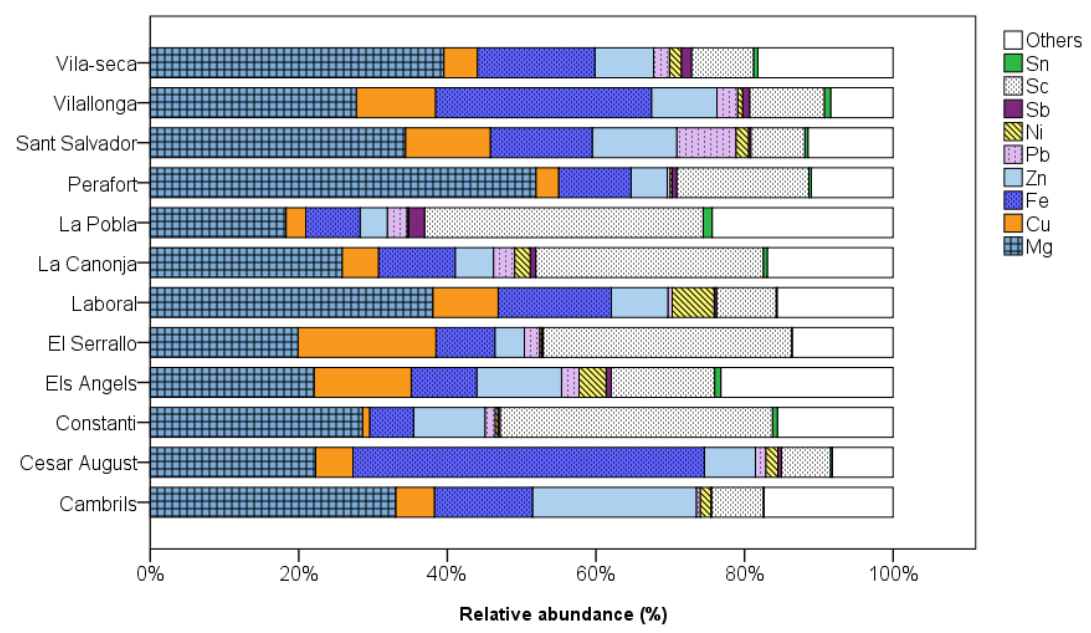

Figure 3: Trace metal element content in $\mathrm{PM}_{1}$ outdoor air of 12 schools in Tarragona. 
$\left(\mathrm{PM}_{2.5}\right)$, in which the most abundant elements were $\mathrm{P}$ and $\mathrm{Cl}$ for $\mathrm{PM}_{10}$ and $\mathrm{PM}_{2.5}$, and $\mathrm{S}$ for $\mathrm{tPM}_{1}$.

\subsection{XRD and SEM findings}

A circular piece of each quartz filter was analyzed by XRD along with samples from sources. Due to the amorphous matrix of fibbers from which the filters are made, a typically diffractogram contains a high background level which has to be removed to find and identify the peaks compared with a mineral database (JCDPS) that represent the crystalline phases present in the samples. The most important phases identified were halite, feldspars, anhydrite and calcite.

Another piece of each sample was observed by SEM-EDS. These results confirmed the presence of halite, among other mineral phases as calcite, anhydrite, silvite, etc. Also, a significative amount of amorphous carbon was observed in most of the samples. These findings are in accordance to previous studies performed in Tarragona [15].

\subsection{Spatial analysis of samples}

From a comparative analysis of the elements and ratios used as traces for identifying the pollution sources in coastal and industrial areas [4], [5], [13], [16], [17], some of them were selected to examine our data, for example, the influence of the predominant wind (NW) thought the transport of the heaviest particles was reflected in the spatial distribution of both the $\mathrm{PM}$ content and in the ratios $\mathrm{PM}_{2.5} / \mathrm{PM}_{10}$ and $\mathrm{PM}_{1} / \mathrm{PM}_{2.5}$ in Tarragona.

The Mn content profile $\left(\mathrm{PM}_{10}, \mathrm{PM}_{2.5}\right.$ and $\left.\mathrm{PM}_{1}\right)$ was quite similar at La Canoja, Els Angels and Cesar August, while was the highest at Vilallonga, which confirms the industrial influence in these schools.

The Ni content, especially in $\mathrm{PM}_{1}$, corresponded to refining and fuel-oil combustion places at Laboral, La Canoja, Els Angel, Cesar August, Sant Salvador and Vilallonga. The highest content was found at Cesar August.

Using Se content as tracer for coal combustion, Vilaseca, Laboral, La Canoja, Els Angel, Cesar August, could be grouped by its content in $\mathrm{PM}_{2.5}$. Perafort had a similar content, but, appears as a northern isolated point.

Laboral, El Serrallo and Sant Salvador had the highest $\mathrm{Cu} / \mathrm{Sb}$ ratios in $\mathrm{PM}_{1}$ which could indicate that they are mostly influenced by road traffic, while El Serrallo and La Pobla had the highest $\mathrm{Al} / \mathrm{Ca}$ ratio in $\mathrm{PM}_{10}$, indicating the places where the resuspended effect is more relevant either by traffic or by construction works.

As previously mentioned, $\mathrm{Na}$ content profile $\left(\mathrm{PM}_{10}, \mathrm{PM}_{2.5}\right.$ and $\left.\mathrm{PM}_{1}\right)$ was almost the same in every place representing the sea sprays and aged sea salts apportionment.

Another important tracer was the $\mathrm{C} / \mathrm{N}$ ratio (see Fig. 4), which is used to evaluate the origin of the organic matter; the obtained ratios were between 0.4 (Cambrils, $\mathrm{PM}_{2.5}$ ) and 53 (La Pobla, $\mathrm{PM}_{10}$ ) with an average value of 13 for $\mathrm{PM}_{1}, 15$ for $\mathrm{PM}_{2.5}$ and 13 for $\mathrm{PM}_{10}$. While Cambrils, El Serrallo and VilaSeca had a profile ratio with values lower than 10 (planktonic source); Sant Salvador, Els Angels and Cesar August lower than 15 (terrestrial vascular plants); La Pobla and Vilallonga ratios were greater to 30: out of the literature reference.

\subsection{Isotope analysis and source identification}

The isotope composition of the whole carbon content in each filter $\left(\delta^{13} \mathrm{C}\right)$ was analyzed by taking a sample of $1 \times 1 \mathrm{~cm}$. The results are expressed in \%o respect to the isotope composition 


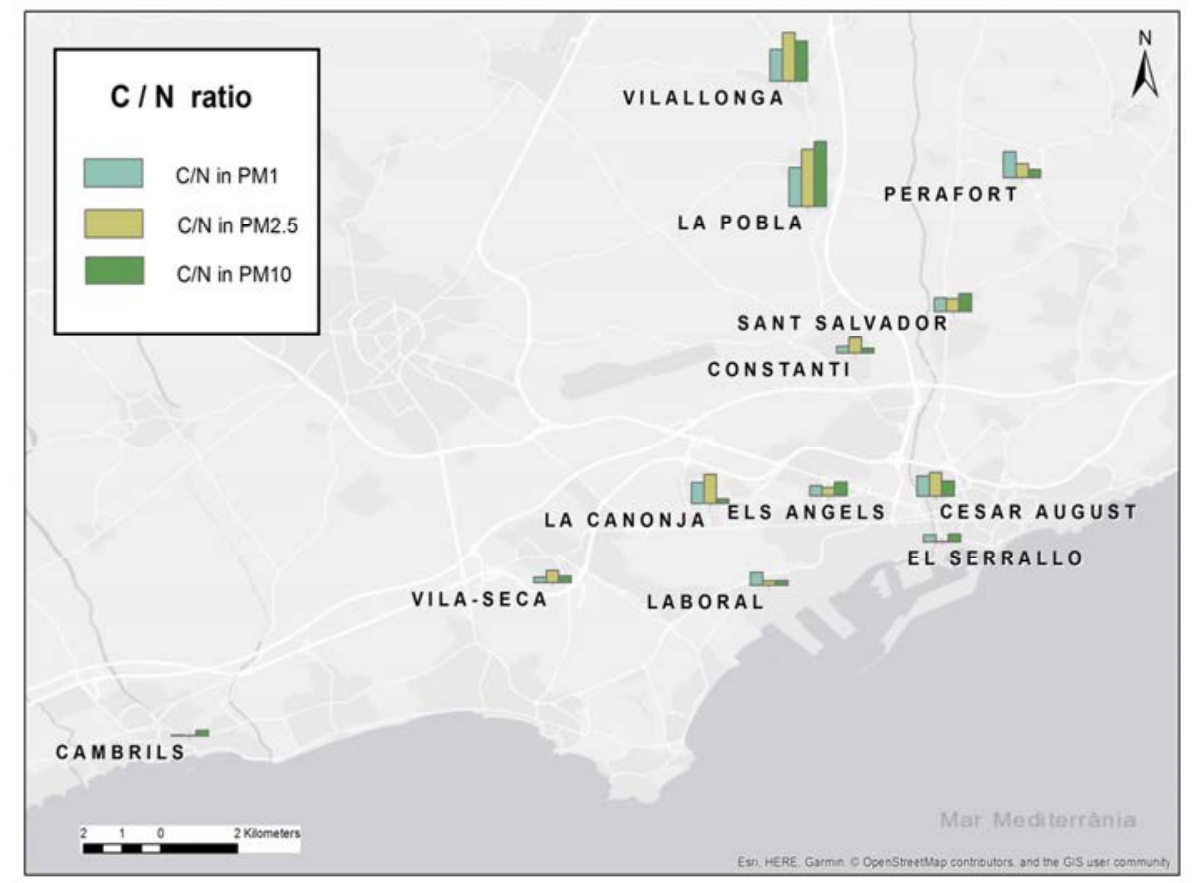

Figure 4: Spatial distribution of $\mathrm{C} / \mathrm{N}$ ratio in PM outdoor air of 12 schools in Tarragona.

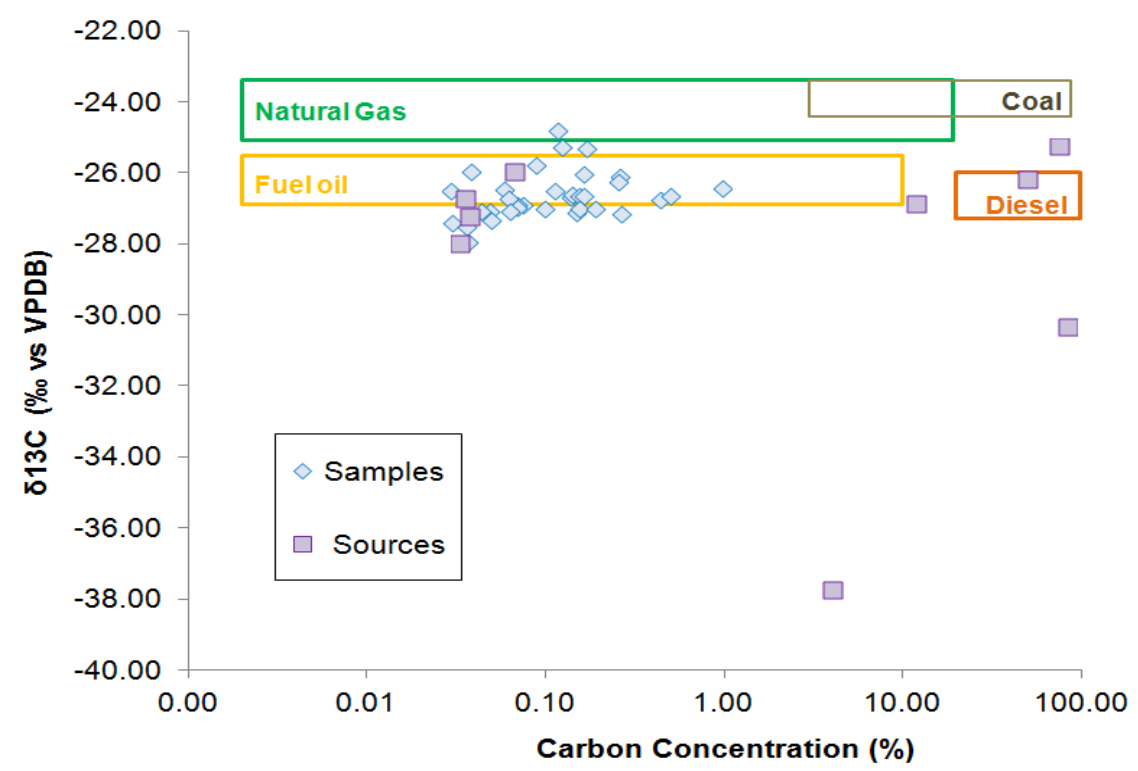

Figure 5: Carbon isotope characterization of PM samples and sources from Tarragona in comparison to reference boxes of different combustion emissions [1]. 
of the international standard for carbon, Vienna Pee Dee Belemnite (VPDB), and are presented in Fig. 5 along with some reference boxes which represent the isotope signature of the combustion products by fuels according to the study of Widory et al., 2004 [1].

All school samples had a $\delta^{13} \mathrm{C}$ significantly different from those associated to mineral fraction $\left(>-17 \%\right.$ ) [13], instead, most of them had a $\delta^{13} \mathrm{C}$ around $-26.6 \%$ which can be associated to fuel oil combustion, in a wide range of carbon content between 0.05 to $1 \%$. Most of the analyzed sources also showed a similar $\delta^{13} \mathrm{C}$, but, its carbon concentration permitted identifying a different combustion fuel.

The overall carbon isotope signature for PM at Tarragona ( $-26.1 \pm 0.8 \%$ for $\mathrm{PM}_{10},-26.8$ $\pm 0.5 \%$ for $\mathrm{PM}_{2.5}$ and $-26.9 \pm 0.4 \%$ of $\left.\mathrm{PM}_{1}\right)$; was quite different of those which are reported for other cities, i.e. Beijin-23.5 $\pm 0.9 \%$ for $\mathrm{PM}_{1}$ or Delhi $-25.5 \pm 0.5 \%$ for $\mathrm{PM}_{10}$, but closer to Kolkata (Calcuta) $-26.0 \pm 0.4 \%$ for $\mathrm{PM}_{10}[2,18]$.

The maximum $\delta^{13} \mathrm{C}$ value for $\mathrm{PM}_{10}$ was $-24.8 \%$ (El Serrallo), -25.7\% (Cesar August) for $\mathrm{PM}_{2.5}$ and $-26.43 \%$ o (Constanti) for $\mathrm{PM}_{1}$; they are all aligned with the predominant wind direction from coast to inland. Whereas the minimum $\delta^{13} \mathrm{C}$ values $(-27.9 \%$ of Cambrils for $\mathrm{PM}_{1},-27.4 \%$ of Laboral for $\mathrm{PM}_{2.5}$ and $-26.7 \%$ of La Pobla for $\mathrm{PM}_{10}$ ) were mainly upwind (near of the coast).

The farthest locations from the coast (Vilallonga, La Pobla and Perafort) shared a similar profile around -26.7\%: $\delta^{13} \mathrm{C}\left(\mathrm{PM}_{10}\right)<\delta^{13} \mathrm{C}\left(\mathrm{PM}_{2.5}\right)<\delta^{13} \mathrm{C}\left(\mathrm{PM}_{1}\right)$.

In general, a spatial overview of the $\delta^{13} \mathrm{C}$ signature revealed a profile that matches very well with the expected influence areas by the macro sources: petrochemical, industrial complex and harbour, although the range of the $\delta^{13} \mathrm{C}$ signature is not large enough to identify the proportion of the different sources with a high level of certainly.

\section{CONCLUSIONS}

Selected elements and ratios seem to be appropriated for PM sources apportionment in Tarragona, while complementary isotopic characterization of PM could help to confirm these results. Moreover, isotopes have more accuracy and demand fewer resources both for pre and post sample analysis.

\section{ACKNOWLEDGEMENTS}

The present research work has been funded by UltraPAR (CTM2015-65303-P), REMEDIATION (CGL2014-57215-C4-1-R) and PACE (CGL2017-87216-C4-1-R) projects from Spanish Ministry of Economy and Competitiveness (MINECO) and co-financed by the European Union through the European Regional Development Fund (AEI/FEDER, UE). This work was also partly supported by the Generalitat de Catalunya though the consolidate research group (2017-SGR-1733). E. Plasencia Sánchez was supported by the Peruvian Government credit-fellowship "Reto Excelencia" and M. Rosell by "Ramón y Cajal" contract RYC-2012-11920. We thank the technical support from CCiT-UB.

\section{REFERENCES}

[1] Widory, D., Roy, S., Le Moullec, Y., Goupil, G., Cocherie, A. \& Guerrot, C., The origin of atmospheric particles in Paris: a view through carbon and lead isotopes. Atmospheric Environment, 38, pp. 953-961, 2004.

[2] Sharma, S.K. et al., Variation of stable carbon and nitrogen isotopic composition of $\mathrm{PM}_{10}$ at urban sites of Indo Gangetic Plain (IGP) of India. Bull Environ Contam Toxicol., 95, pp. 661-669, 2015. 
[3] Widory, D., Nitrogen isotopes: Tracers of origin and processes affecting $\mathrm{PM}_{10}$ in the atmosphere of Paris. Atmospheric Environment, 41, pp. 2382-2390, 2007.

[4] Mbengue, S., Alleman, L.Y. \& Flament, P., Metal-bearing fine particle sources in a coastal industrialized environment. Atmospheric Research, 183, pp. 202-211, 2017.

[5] Di Palma, A. et al., Geochemistry and carbon isotopic ratio for assessment of $\mathrm{PM}_{10}$ composition, source and seasonal trends in urban environment. Environmental Pollution, 239, pp. 590-598, 2018.

[6] Kunwar, B., Kawamura, K. \& Zhu, Ch., Stable carbon and nitrogen isotopic compositions of ambient aerosols collected from Okinawa Island in the western North Pacific Rim, an outflow region of Asian dusts and pollutants. Atmospheric Environment, 131, pp. 243-253, 2016.

[7] Querol, X. et al., Speciation and origin of $\mathrm{PM}_{10}$ and $\mathrm{PM}_{2.5}$ in selected European cities. Atmospheric Environment, 38, pp. 6547-6555, 2004.

[8] Aragón Guiol, M., Caracterització de l'atmosfera del port de Tarragona. PhD thesis, Tarragona, 2013 (in Catalan).

[9] Alastuey, A. et al., Contribution of harbour activities to levels of particulate matter in a harbour area: Hada Project-Tarragona Spain. Atmospheric Environment, 41, pp. 6366-6378, 2007.

[10] Querol, X. et al., Levels of particulate matter in rural, urban and industrial sites in Spain. Science of the Total Environment, 334-335, pp. 359-376, 2004.

[11] Querol, X. et al., Speciation and origin of $\mathrm{PM}_{10}$ and $\mathrm{PM}_{2.5}$ in Spain. Aerosol Science, 35, pp. 1151-1172, 2004.

[12] Rodriguez, S. et al., Comparative $\mathrm{PM}_{10}-\mathrm{PM}_{2.5}$ source contribution study at rural, urban and industrial sites during PM episodes in Eastern Spain. Science of the Total Environment, 328, pp. 95-113, 2004.

[13] Mari, M. et al., Source apportionment of inorganic and organic PM in the ambient air around a cement plant: Assessment of complementary tools. Aerosol and Air Quality Research, 16, pp. 3230-3242, 2016.

[14] Moreno, T. et al., Variations in atmospheric PM trace metal content in Spanish towns: Illustrating the chemical complexity of the inorganic urban aerosol cocktail. Atmospheric Environment, 40, pp. 6791-6803, 2006.

[15] Alastuey, A. et al., Contribution of harbour activities to levels of particulate matter in a harbour area: Hada Project-Tarragona Spain. Atmospheric Environment, 41, pp. 6366-6378, 2007.

[16] Moreno, T. et al., Variations in atmospheric PM trace metal content in Spanish towns: Illustrating the chemical complexity of the inorganic urban aerosol cocktail. Atmospheric Environment, 40, pp. 6791-6803, 2006.

[17] Sánchez de la Campa, A. et al., High concentrations of heavy metals in PM from ceramic factories of Southern Spain. Atmospheric Research, 96(2010), pp. 633-644, 2010.

[18] He, N., Kawamura, K., Kanaya, Y. \& Wang, Z., Diurnal variations of carbonaceous components, major ions, and stable carbon and nitrogen isotope ratios in suburban aerosols from northern vicinity of Beijing. Atmospheric Environment, 123, pp. 18-24, 2015. 